\title{
CRANIO-ORBITAL APPROACH FOR THE PARACLINOIDAL AND ANTERIOR COMMUNICATING ANEURYSMS
}

\author{
JORGE MARCONDES DE SOUZA*, FLÁVIO F. RODRIGUES ${ }^{* *}$, MARCELO R. DA SILVA***, RICARDO \\ MARON***, LEONARDO MARTINS****, ANTONIO A. DO SOUTO ${ }^{* \star * *}$, LUCIARA S. LIMA***
}

\begin{abstract}
SUMMARY - Aneurysms arising at the proximal intracranial carotid artery (between cavernous sinus and posterior communicating artery) and at the anterior communicating complex may present with technical difficulties regarding appropriate access without excessive brain retraction. In a series of 15 patients the authors show the use of the cranio-orbital approach, formerly designed in the access of skull base tumors, for these subgroups of aneurysms. They discuss the advantages of a basal avenue in minimizing brain retraction, better anatomical orientation, obviation of tissue ressection and easier extra-dural bone removal. It was not identificd any complication due to the described approach.
\end{abstract}

KEY WORDS: intracranial aneurysms, paraclinoidal aneurysms, skull base surgery, subarachnoid hemorrhage.

Acesso crânio-orbital para aneurismas paraclinóideos e da comunicante anterior

RESUMO - Aneurismas situados junto à artéria carótida intracraniana proximal (entre seio cavernoso c artéria comunicante posterior) e ao nivel do complexo comunicante anterior podem apresentar dificuldades técnicas relacionadas ao acesso apropriado sem retração cerebral excessiva. Em uma série de 15 pacientes os autores mostram o uso do acesso crânio-orbital, utilizado inicialmente para abordagem a tumores da base do crânio, para esses subgrupos de aneurismas. Discutem suas vantagens em minimizar retração, melhor orientação anatômica, evitar ressecção de tecido neural e facilitar remoção óssea. Não foi identificada qualquer complicação devida ao acesso descrito.

PALAVRAS-CHAVE: aneurisma intracraniano, aneurisma paraclinóideo, cirurgia da base do crânio, hemorragia subaracnóidea.

Aneurysms of the anterior circulation are usually approached through a pterional intradural access. Anterior communicating complex (A.co.A) and paraclinoidal aneurysms pose difficulties due to their deep situation, usually requiring brain retraction and, in the case of A.co.A., some gyrus rectus resection in order to be better visualized. In 1982, Jane et al. described the supra orbital approach for orbital tumors, craniopharyngiomas, pituitary tumors and anterior communicating aneurysms $\mathrm{s}^{9}$. They mentioned a Yasargil's personal communication in which a separated orbital rim flap was done after frontal craniotomy. Smith et al. confirmed that, by an orbitocranial flap ${ }^{14}$. Recent advances in cranial base surgery, mainly toward tumor resection, allowed operations at the base of the brain obviating tissue damage due to protracted retracion. Al-Mefty et al. described the cranioorbital zygomatic approach for skull base tumors involving anterior and middle fossae regions

Service of Neurosurgery, Department of Surgery, Hospital Universitário Clementino Fraga Filho, Universidade Federal do Rio de Janeiro. (UFRJ): *Professor of Neurosurgery; **Professor and Chief of Neurosurgery; ${ }^{* * *}$ Associated Neurosurgeon; ${ }^{* * * *}$ Resident. Aceite: 22 -abril-1995. 
affording an excellent subfrontal, and trans-sylvian access bringing the surgeon closer to a deep seated lesion with a single bone flap ${ }^{1}$. Origitano and Anderson mentioned the additional advantage of the cranio-orbital approach for aneurysms of the anterior circulation deeply situated ${ }^{10}$. Sekhar et al. recently described the use of cranial base approaches in dealing with intracranial aneurysms ${ }^{13}$.

The authors have been using the cranio-orbital approach in the last two years, finding it advantageous when compared with the pterional access in the refered situations. The results in a series of 15 patients is reported.

\section{OPERATIVE TECHNIQUE AND CLINICAL MATERIAL}

\section{Operative technique}

The positioning includes patient supine with the head rotated thirty degrees to the opposite side, tilted five to ten degrees downward and fixed in the Mayfield headrest. A lumbar drain is inserted just in case it is needed, like in the posteriorly oriented A.co.A. and in all cases of paraclinoidal aneurysms. Manitol $20 \%$ is infused, at the total of $500 \mathrm{cc}$ during the craniotomy.

A bicoronal incision is done, preserving the pericranial layer for later closure of the frontal sinus. The supraorbital nerve is freed from its foramen and the periorbit is carefully dissected from the orbital bony walls (Fig l).

We used to follow the temporalis muscle dettachment described by Yasargil ${ }^{15}$ but recently changed for Ammirati's variation ${ }^{2}$ in order to better protect the temporal branch of the facial nerve. The first burr hole is frontal, above the nasion, entering the frontal sinus and drilling its posterior wall; two other burr holes are the "key hole" and another one posteriorly to and lower than it, on the temporal margin of the incision. While protecting the periorbit, the "key hole" is connected to the frontal one using the Gigli's saw; the frontal and temporal holes are connected with the craniotome raising an one-piece flap (Fig 2).

The remaining roof of the orbit is removed and the sphenoid wing drilled.

In the cases of aneurysms of the A.co.A. complex it is ready to proceed with dural opening at the base of the frontal lobe. In the of paraclinoidal aneurysms (superior hypophyseal ophthalmic and carotid cave) the drilling is continued, passing the superior orbital fissure, medial sphenoid wing, optic nerve unroofing and



Fig 1. The periorbital dissected from the orbital bony wall. 


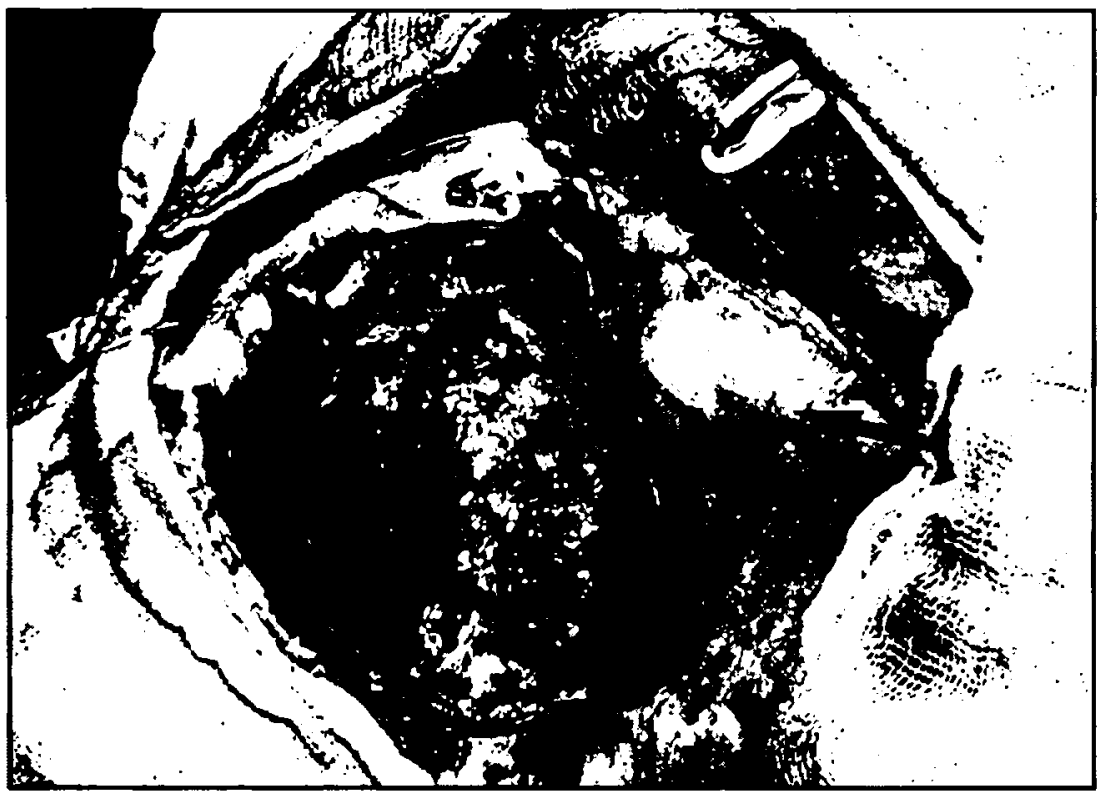

Fig 2. Afier bone flap elevation, the low frontal exposure and aspect of the periorbit without the orbital roof.

Table 1. Cranio orbifal approach for aneurysm.

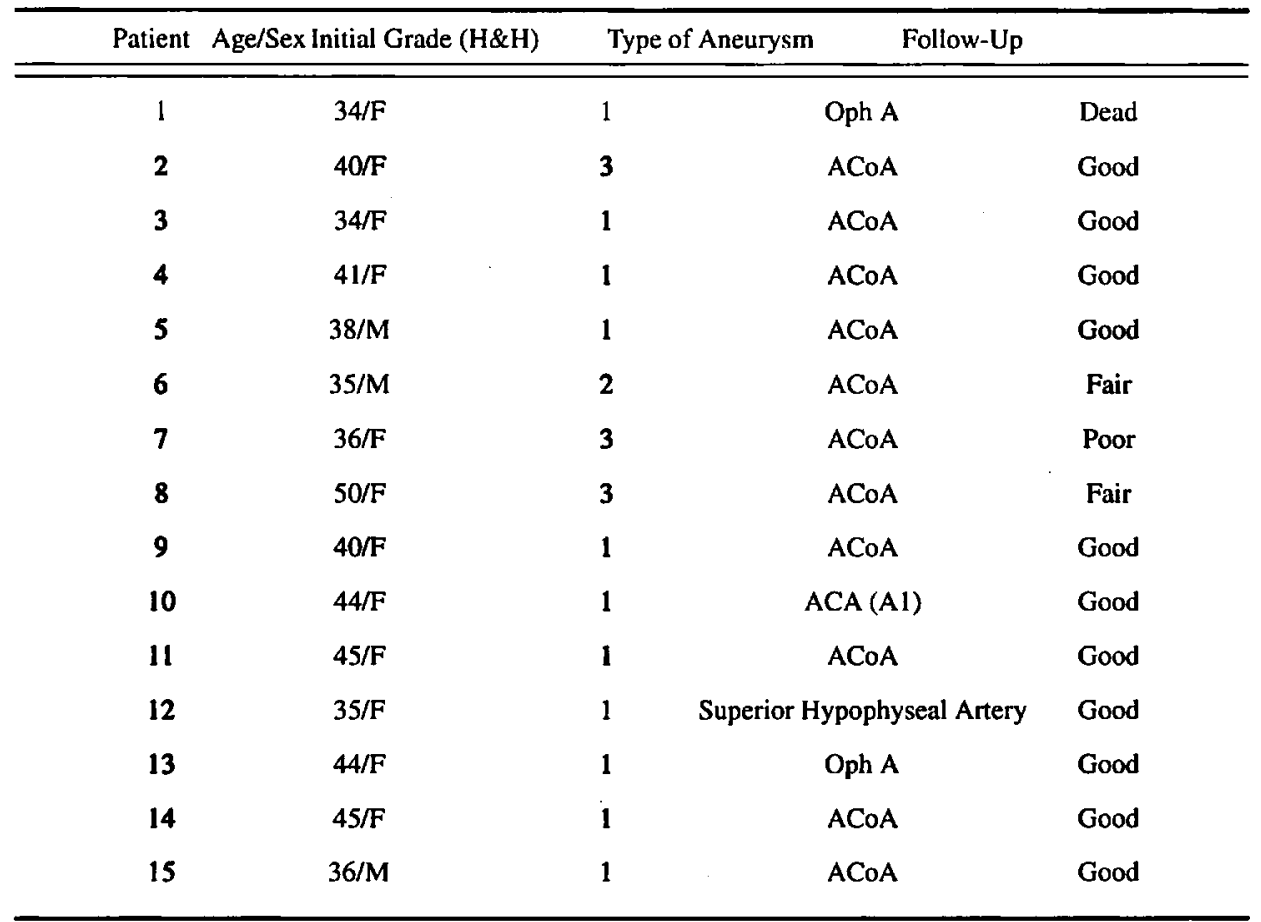


anterior clinoid coring, as proposed by Dolenc ${ }^{7}$. Although the intradural resection of the anterior clinoid process has been advocated as safer, we feel comfortable with the extradural dissection and drilling, having the dural protection and the more extensive optic canal opening allowing better optic nerve mobilization.

After dural opening, a minimal gentle elevation of the orbital gyruses will show at a short distance the $A_{1}$ segment crossing the optic nerve. After dissection of arachnoid bands around the optic nerve and chiasm the contralateral $A_{1}$ will come in the view, making the dissection of both $A_{2}$ and the aneurysm much safer. There is no need for gyrus rectus resection. Such orientation is particularly helpful in the large and superiorly oriented aneurysms.

In the case of paraclinoidal aneurysms, the dural opening continues through the falciform ligament.

In the case of large aneurysms it is usually necessary to open the distal dural ring around the internal carotid artery (clinoidal segment) for a better proximal control. Fenestrated clips are the best choice for the superior hypophyseal variant with its medial projection ${ }^{4,6}$, always being important a final cheking for significant stenosis or kinking of the carotid artery (Fig 3 and 4). In all patients harboring a paraclinoidal aneurysm, the cervical internal carotid artery was prepared for temporary occlusion in case it was needed.

\section{Clinical material}

The cranio-orbital approach was used in 15 patients, being 12 A.co.A. complex and 3 paraclinoidal aneurysms.

Age mean was 36.7 years (34-50), being 12 females and 3 males. The mode of presentation, with Hunt and Hess grade at the time of surgery and the final outcome is shown in Table 1. We used the following scale for outcome evaluation: good, no functional impairment, return to occupation and may have minor unilateral visual loss; fair, lives independently, moderate visual impairment or minor focal deficit; poor, unable to live independently: dead.

All the patients received antibiotic prophylaxis with Oxacilin $2 \mathrm{~g}$ E.V. and were at nimodipine. (60mg every 4 hours), except for Patient 13 that presented with unilateral visual loss.

\section{RESULTS}

We had $73.3 \%$ of patients graded as good (11 patients), 13,3\% fair (2 patients), and one poor result. One patient died within the first two weeks post-operative, being a case of giant ophthalmic aneurysm that ruptured at the final dissection but was safety clipped at its neck. The patient awaked without deficit. After the $4^{\text {th }}$ post operative day she developed headaches, fever and progressive

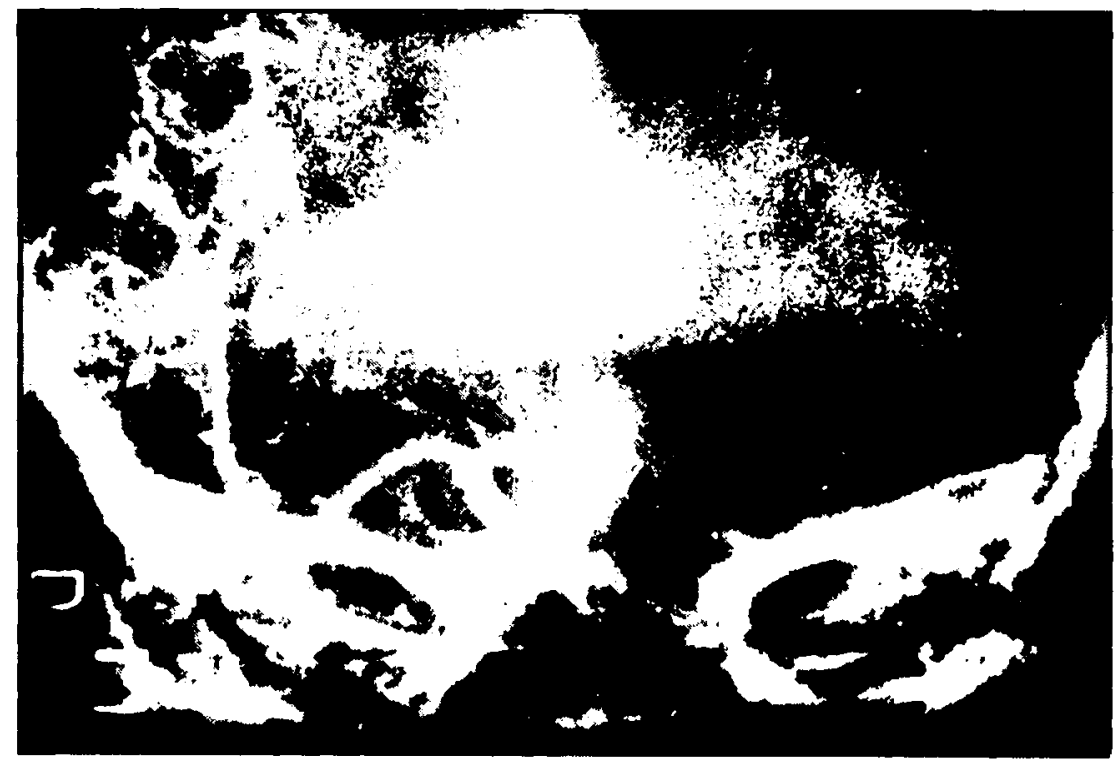

Fig 3. Large superior hypophyseal artery aneurysm with its typical medial orientation. 


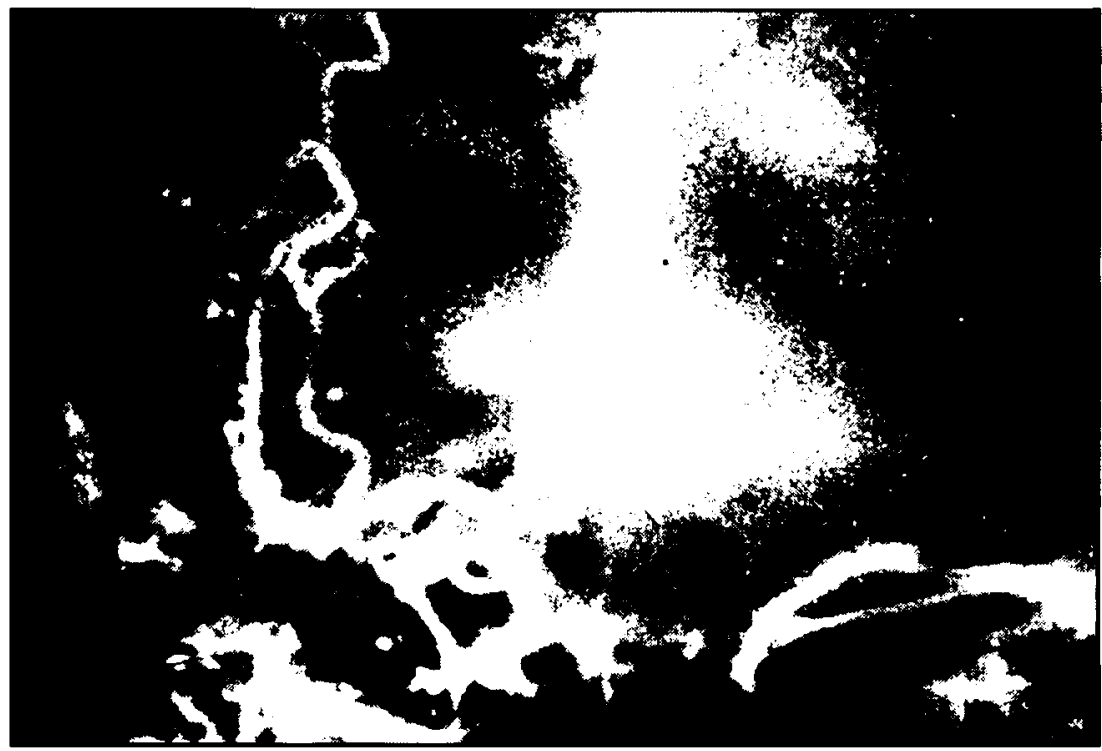

Fig 4. The aneurysm clipped with the fenestration involving the carotid artery.

confusion. CT scan and CSF examination were normal. She deteriorated in spite of hypervolemichypertensive therapy.

Two patients died more than two months after surgery. One of them from meningitis from infected shunt having been already bedridden due to tetraparesis from severe vasospasm before surgery (patient 7). Another died from myocardial infarction after discharged in a fair grade (patient 8 ).

We had a case of superficial infection cured with antibiotics. There were no instant of exo-or enophthalmos as well as cosmetic deformity.

Two patients had to be reoperated for repositioning the clip, both of them having A.co.A aneurysms and neither of them changing their degree after the second procedure.

\section{COMMENTS}

The traditional approaches described for the A.co.A. aneurysms as the subfrontal of Gardners, subfrontal bilateral of Pool " and fronto-lateral of Dandy ${ }^{5}$ as weed as the ones more recently designed as the pterional of Yasargil et al ${ }^{15}$ have always emphasized the importance of avoiding excessive brain retraction. Some advocated gyrus rectus resection in order to maximize visualization.

The very low basal access afforded by the cranio-orbital operation keeps the tissue manipulation at the minimum necessary ${ }^{3}$, maintaining the straight orientation with the imediate and safer localization of both $A_{1}$ segments before any dissection of the aneurysm and also obviating the gyrus rectus resection.

When dealing with the paraclinoidal aneurysms, the cranio-orbital approach has the additional advantage of driving the surgeon faster toward the superior orbital fissure, anterior clinoid and roof of the optic canal, with better untethering of the optic nerve and anterior clinoid resection than intradurally. Rhoton and Inoue advise about the possibility of calcification connecting the anterior and middle clinoid processes, transforming the distal end of the carotid sulcus into an ostium called carotico clinoid canal, where the extraction of the anterior clinoid shelf can be very dangerous (as in our Patient 13) ${ }^{12}$. In that case the drilling of the clinoid rests would be safer. We suggest that in every case where the clinoid extraction is antecipated, a high resolution CT scan should be done, with thin slices and bone windows checking for this type of bony bridge. 
We have not seen any increase of incidence of infections, cosmetic problems or frontal dysesthesias due to supraorbital nerve dettachment in this selected population.

\section{CONCLUSIONS}

The authors present their initial experience with the cranio-orbital approach for the paraclinoidal and anterior communicating complex aneurysms. In this selected population, the advantagens of the method are several fold:

1. It affords minimal brain retraction in deep seated aneurysms.

2. Achieves immediate and frontal visualization of both $A_{1}$ segments, with its attending safety and better anatomical orientation in approaching A.co.A. aneurysms, especially the large and superiorly oriented ones.

3. A more complete drilling of the lesser sphenoid wing and anterior clinoid plus a better untethering of the optic nerve, when dealing with paraclinoid aneurysms, than with the intradural route.

\section{REFERENCES}

1. Al-Mefty O, Ayoubi S, Schenk M. Unlocking and entering the cavernous sinus. Persp Neurol Surg 1991, 2: 49-68.

2. Ammirati M, Spallone A, Ma J, Cheathan M, Becker D. An anatomicro surgical study of the temporal branch of the facial nerve. Neurosurgery 1993, 33:1038-1044.

3. Andrews $\mathrm{R}$, Bringa $\mathrm{J}$. A review of brain retraction and recommendations for minimizing intraoperative brain injury. Neurosurgery 1993, 33:1052-1064.

4. Batjer HH, Kopitnik TA, Giller CA, Samson D. Surgery for the paraclinoidal carotid artery aneurysms. J Neurosurg 1994, 80: 650-658.

5. Dandy WE. Aneurysms of the anterior cerebral artery. JAMA 1942, 119:1253.

6. Day AL. Aneurysms of the ophthalmic segment: a clinical and anatomical analysis. J Neurosurg 1990, 72 : 677-69I.

7. Dolenc VV. A combined epi- and subdural direct approach to carotid-ophthalmic artery aneurysms. J Neurosurg 1985, 62:667-672.

8. Gardner WJ. Cerebral angiomas and aneurysms. Surg Clin North Am 1936, 16:1019-1030.

9. Jane JA, Park TS, Pobereskin LH, Winn R, Butter A. The supraorbital approach: technical note. Neurosurgery 1982, 11:537-542.

10. Origitano TC, Anderson D. Skull base approach for aneurysms. Surg Neurol 1993, 40:339-346.

11. Pool JL. Bifrontal craniotomy for anterior communicating aneurysms: J Neurosurg 1972, 36:2 I2-220.

12. Rhoton AL, Inoue T. Microsurgical approaches to the cavernous sinus. Clin Neurosurg 1991, 37:391-439.

13. Sekhar LN. Kalia KK, Yonas H, Wright DC, Ching H. Cranial base approaches to intracranial aneurysms in the subarachnoid space. Neurosurgery 1994, 35:472-483.

14. Sinith RR, Al-Mefty O, Middleton TH. An orbitrocranial approach to complex aneurysms of the anterior circulation. Neurosurgery 1989, 24:385-391.

15. Yasargil ME, Fox JL, Ray MW. The operative approach to aneurysms of the anterior communicating artery. In Krayenbuh $1 \mathrm{H}$ (ed). Advances and technical standards in neurosurgery. Stuttgart: Springer-Verlag, 1975. p. $113-170$. 